\title{
THE IMPORTANCE OF THE INTERACTIVE LECTURE IN THE STUDY OF “METHODOLOGY OF RESEARCH WORK” ACADEMIC DISCIPLINE IN THE PROCESS OF BACHELOR NURSES TRAINING
}

\author{
В. М. Косенко \\ Житомирський медичний інститут Житомирської обласної ради \\ ЗНАЧЕННЯ ІНТЕРАКТИВНОЇ ЛЕКЦІЇ ПРИ ВИВЧЕННІ НАВЧАЛЬНОЇ
ДИСЦИПЛІНИ «МЕТОДОЛОГІЯ НАУКОВО-ДОСЛІДНОЇ РОБОТИ»
В ПРОЦЕСІ ПІДГОТОВКИ МЕДИЧНИХ СЕСТЕР-БАКАЛАВРІВ
}

Abstract. In this article is presented the significance and importance of the interactive lecture in the study of "Methodology of Research Work" academic discipline by the future bachelor nurses. It is indicated that the increasing educational needs of the higher education seekers direct and guide the instructors of the higher educational establishments to use and introduce new forms and methods of study. It is emphasized that presentation of finished theoretical material by the instructor is the least efficient way to perceive and remember new information. The processes of remembering can be positively influenced through the attraction of the higher education seekers to active interaction. The positive point of the "lecturer-student" cooperation is a constant extending of the range of opinions, among which it is necessary to choose the most rational. Learning by doing is the best way for comprehension of the most complicated theoretical material. Application of the interactive technologies is analyzed with specific reference related to the conduct of a lecture session in the study of "Methodology of Research Work" academic discipline. The article lists structural constituents, describes advantages and factors affecting the retention of auditory material in virtue of the interactive technologies. It is indicated that the instructor should use the time allotted for classes with maximum effect for the student, given the reduction in the number of class hours. The interactive lecture organically combines methodological, didactic and educational functions and creates the optimal conditions for the constant activation of the cognitive activity of the higher education seekers, allowing to realize the creative potential and provide each student with the opportunity to become the main subject of study, see and independently evaluate the diversity of opinions and approaches when solving important for further professional activities tasks. The realities of our time require the improvement of methodological and professional competence of the instructors of the higher educational establishments.

Key words: interactive lecture; importance; nurses; study.

Анотація. У статті проаналізовано значення та важливість інтерактивної лекції в процесі вивчення навчальної дисципліни «Методологія науково-дослідної роботи» майбутніми медичними сестрами-бакалаврами. Вказано, що зростаючі освітні потреби здобувачів вищої освіти націлюють та орієнтують викладачів ЗВО на застосування та впровадження нових форм і методів навчання. Акцентується увага на твердженні, що подання готового теоретичного матеріалу викладачем - найменш ефективний спосіб сприйняття та запам’ятовування нової інформації. На процеси запам’ятовування можна позитивно вплинути, залучаючи здобувачів вищої освіти до активної взаємодії. Позитивним моментом співпраці «лектор-студенти» $є$ те, що постійно розширюється коло думок, серед яких необхідно вибрати найбільш раціональні. Знання через дію - найкращий шлях до засвоєння найскладнішого теоретичного матеріалу. Застосування інтерактивних технологій аналізується на конкретному прикладі, пов'язаному з проведенням лекційного заняття в процесі вивчення навчальної дисципліни «Методологія науководослідної роботи». У статті перераховано складові структури, описано переваги та фактори, які впливають на ефективність лекції на основі інтерактивних технологій. Вказано, що викладач має використати час, відведений на заняття, з максимальним ефектом для студента, враховуючи скорочення кількості аудиторних годин. Інтерактивна лекція органічно поєднує методичну, дидактичну та виховну функції та створює оптимальні умови для постійної активізації пізнавальної діяльності здобувачів вищої освіти, дозволяє розкрити творчий потенціал та надати можливість кожному студенту стати головним суб’єктом навчання, побачити та самостійно оцінити різноманітність думок та підходів при вирішенні важливих для подальшої фахової діяльності завдань. Реалії сьогодення потребують удосконалення методичної грамотності та професійної компетентності викладачів 3 ВО.

Ключові слова: інтерактивна лекція; значення; медичні сестри; навчання.

Introduction. Achievement of objectives related to the training of highly qualified, competitive specialists in the subject area 22 Healthcare in specialty 223 Nursing requires the introduction of modern interactive

\footnotetext{
(c) V. M. Kosenko
} 
methods in lectures and practical classes at all stages of health personnel training.

One of the mandatory types of academic work is a lecture, which creates a thorough and fundamental base of theoretical knowledge necessary to solve professionally important problems [1].

Lecture is a universal method of transmitting compactly formed information simultaneously to a large number of listeners [1]. The modern presentation of the lecture material is markedly different from the generally accepted [6-8]. The increasing educational needs of the higher education seekers direct and guide the instructors of the higher educational establishments to use and introduce new forms and methods of study [3, 4]. The special attention is paid to information technology [2]. Unlike the traditional one, the interactive lecture minimizes the instructor's monologue, preferring a dialogue between the lecturer and the students, during which the higher education seekers gradually acquire the essential and professionally important competencies [5]. Lecture should intensify the desire to learn more and farther through additional individual working on the topic. The main purpose of lectures is to arouse the interest of students in academic discipline and to encourage systematic and persistent work.

Methodological basis of research are the works dedicated to disclosure of theoretical framework related to the use of interactive teaching methods in the process of training of the higher education seekers [2, 5, 7]. L. A. Hai et al. (2016), V. V. Nahornyi (2016), I. Ya. Krynytska et al. (2018), U. M. Mudryk et al. (2020), P. O. Herasymchuk et al. (2021) have studied different aspects of the interactive session $[2-5,7]$. However, the question of introducing modern teaching methods at the lectures in the process of bachelor nurses training needs deeper research, which prompted to writing the article.

The aim. Justify the feasibility and prospects of a lecture in "Methodology of Research Work" academic discipline basing on interactive methods and technologies.

Methods. The study used the bibliosemantic method, the method of system analysis and logical generalization.

Results. Research work is one of the main components of the educational process, which provides high-quality training of specialists in the subject area 22 Healthcare in specialty 223 Nursing. The higher educational establishments provide for its various forms - this is the participation of students in the work of scientific circles, the fulfillment of independent scientific research tasks, the presentation of theses for participation in scientific student conferences, the submission of articles, scientific abstracts, competitive scientific papers, etc. Qualitative and full-fledged scientific research is impossible without basic knowledge of the foundations of research work methodology. Familiarity with the main methodological concepts, the study of methods and principles, the sequence of stages of research work helps in the correct selection of topics, the formation of goals, tasks, object and subject of research, the definition of practical and theoretical importance, the organization and conduct of the stage related to the collection of new information, presentation of results and their demonstration.

"Methodology of Research Work" academic discipline helps to form the ability of future medical professionals (bachelor nurses) to analyze, synthesize, sum up scientific information that is important for professional formation and development, to illuminate the results of research in scientific works. The training course includes lectures and practical classes, independent work of students and performance of individual research independent work.

Among the materials of the lecture course, the topic of "Documentary sources of scientific information. Principles of scientific work organization" should be highlighted. The lecture plan provides for the coverage of issues related to the characteristics of documentary sources of scientific information, the method of working on printed literary sources, and the peculiarities of the organization of the researcher's work. The issues are extremely important and complex.

At the preparatory stage, the lecturer should consider what modern teaching methods and technologies should be applied, so that higher education seekers could understand the issues of the topic to the best of their abilities and later use them in the process of training and professional activities. Only an organic combination of interactive methods and technologies would help with this difficult task.

The lecture on "Documentary sources of scientific information. Principles of scientific work organization" should be carried out with elements of visualization in combination with a "rapid-fire interview" and "microphone" methods. Transformation of verbal material into visual form by means of technical means, constant stimulation of listeners for reflection is positively reflected on the topic learning. The instructor may use various forms of visualization: presentation, drawings, diagrams, and handout. All information is encoded in the form of certain characters, signs commented by the 
lecturer, bringing students into the discussion of issues. The lecture with elements of visualization can be most effectively used in presenting generalizing topics, as well as at the beginning of study in order to increase the interest of future bachelor nurses in studying a new educational discipline, in particular, when presenting the topic of "Documentary sources of scientific information. Principles of scientific work organization".

The structure of the class should include: organizational aspect, motivation of educational and cognitive activities, acquisition and consolidation of new knowledge, summing up. Each component is extremely important and affects the final result associated with learning of the topic of the lecture.

The skillful motivation of the topic affects the interest of the audience in understanding the content of the issues reflected in the plan. At the beginning of the lesson, it is appropriate to ask the students: "Why the future nurse, who connects her future only with the practical work in medical preventive institutions, needs knowledge on the topic that is proposed for consideration?"

Considering that only an integrated approach can ensure the development of a holistic system of knowledge, skills and abilities necessary for a specialist to perform professional duties, an important consideration should be given to interdisciplinary relationships. In establishing interdisciplinary relationships, it is necessary to pay attention to previous (enabling) disciplines, subsequent disciplines and intra-subject linkages. Students should understand the value of the obtained theoretical material in the process of further study and professional activity.

At each stage of the lecture, it should be borne in mind that the presentation of the finished theoretical material by the instructor is the least efficient way to perceive and remember. It is common knowledge that information is remembered in arithmetic progression, but is forgotten geometrically. The processes of remembering can be positively influenced through the attraction of the higher education seekers to active interaction. A modern student needs to be interested, not forced.

During the lecture, the instructor can ask questions both to all students present in the classroom and to each student individually. For example, explaining the classification of scientific documents, it is appropriate to ask: "Why handwritten documents are not published by printing means? Why the secondary documents always outnumber the primary ones?” There is nothing against suggesting the students to complete the unfinished scheme (with arrows to indicate which general and special functions the scientific documents perform). The unconstrained dialogue with the audience increases the efficiency of the lesson. The positive point of the «lecturer-student» cooperation is a constant extending of the range of opinions, among which it is necessary to choose the most rational. The task of the lecturer is not only to clearly and intelligibly explain the new material, skillfully formulate issues that need to be resolved. The lecturer has to organize a creative process of their solving, attracting the maximum number of higher education seekers to discuss and make a group decision. Learning by doing is the best way for comprehension of the most complicated theoretical material.

"Methodology of Research Work" academic discipline promotes analytical thinking, creative approaches to solving the most complex issues of today among students. A student who is constantly engaged in research will always find a non-standard solution to the problem in a non-standard situation, which is important in the profession of a nurse.

The interactive lecture is characterized by a twoway flow of information (from the lecturer and from the students), and extemporaneous speeches of listeners enhance the effect of interest. The main role of the instructor is to skillfully organize and control the course of the discussion on the topic, unobtrusively, expressing his/her views. Viewing thematic videos and presentations heightens interest in understanding lecture material and further in-depth study of topics.

The main task of the traditional lecture was to transfer "ready" knowledge to the students. Usually, the lecturer dictated the text, and students mechanically recorded it. Modern higher education seekers are not interested in passive information perception. They can find lecture materials on the websites of the institution. So they wonder: "Why take notes when we can read it?". Modern student wants to perceive new information in modern ways. It is well known that the more analyzers are used, the better and clearer the new material is remembered. At the lecture session, the higher education seekers can take part in an electronic survey, check their level of retention of material by testing, or by asking questions of each other.

The harmonious combination of modern teaching methods at the lecture on "Methodology of Research Work" ensures acquisition by the students of the essential and professionally important competencies: the ability to study as well as to study on their own, the ability to be critical and self-critical, the ability to 
find, process and analyze information from various sources, the ability to abstract and analytical thinking and generation of ideas, the ability to use information and communication technologies.

The benefits of interactive lecture: a higher level of student activity in the perception of new material; the ability to transmit more information by maintaining a high level of attention and interest. The instructor should use the time allotted for classes to best advantage for the student, considering the reduction in the number of classroom hours.

Among the factors affecting the efficiency of the lecture, attention is drawn to: thorough preparation of the main provisions of the lesson, visual aids, technical and methodological support (at the preparatory stage); accessible, coherent presentation of material, application of different methods of attention activation by means of two-way intellectual-emotional contact with audience (during the lesson).

The interactive lecture organically combines methodological, didactic and educational functions and creates optimal conditions for constant activation of cognitive activity of the higher education seekers.

The positive results can be achieved by observing the following requirements: bringing (at the beginning of the lesson) the goal of the lecture and its corresponding motivation to the students, accessibility of presentation, constant feedback, establishing dynamic interaction with the higher education seekers, completing each question with summing up and motivated transition to the next one, emotionality and expressiveness of presentation.

At the preparatory stage, the lecturer should think about the method of checking the digestion of new material by the audience. It is appropriate to use the rapid-fire interview method. Students should answer the questions, which were considered during the lecture session, with one sentence. The higher education seekers can formulate questions on their own and ask them each other. For example, among the clearly defined questions may be the following:

1. What groups of scientific and technical information documents do you know?

2. What form of documents does the preprint belong to?

3. What criteria for evaluating documentary sources of information do you remember?

4. List the general functions of scientific documents.

5. What factors influence the efficiency of mental work?

The lesson will be incomplete if the lecturer does not draw conclusions and answers the possible questions of the audience. Students should generalize their work as well. At the final stage, it is advisable to use an interactive method - a microphone. This method allows each student to quickly express his opinion on the new material studied in a certain order.

For instance,

- I realized the importance of today's topic for further training and professional activities.

- I liked the constant and relaxed work in the group.

- My attention was attracted to the simplicity of the presentation of complex material.

- Illustration and visibility helped to understand the issues of the topic.

It is also worth to give students an understanding that the deepest knowledge is those received independently and to offer multi-level tasks (writing scientific papers; presentation design; writing theses for the conference), indicating how further practical exercises will be evaluated.

The strategy of reforming the higher medical school aims to train a specialist with wide theoretical knowledge, erudition, an appropriate level of practical skills, ability to make logical, reasonable decisions in professional situations. It is "Methodology of Research Work" academic discipline that allows to master scientific methods of obtaining knowledge for in-depth and creative assimilation of educational material of general, professional and practical training cycles. The ability to analyze, synthesize, summarize professionally important information creates the basis for obtaining the training outcomes necessary for successful performance of professional tasks.

Conclusions and Prospects for Research. The current level of training of future bachelor nurses guides the instructor on the transition from traditional methods of reporting information to the introduction of interactive technologies.

The lecture on "Documentary sources of scientific information. Principles of scientific work organization" should be carried out with elements of visualization in combination with a "rapid-fire interview" and "microphone" methods, allowing creating comfortable conditions for higher education seekers, in which everyone feels his success and intellectual ability.

The realities of our time require the improvement of methodological and professional competence of the instructors of the higher educational establishments.

Further study of the issue under consideration requires comparative analysis of the efficiency of modern interactive technologies based on the survey of the higher education seekers. 


\section{List of literature}

1. Біляєва О. М. Сучасна академічна лекція / О. М. Біляєва // Світ медицини та біології. - 2015. - № 4 (53). C. 143-146. - Режим доступу : http://nbuv.gov.ua/ UJRN/S_med_2015_4(53)_39.

2. Використання активних форм навчання та сучасних інформаційних технологій як засобу інтенсифікації навчального процесу / У. М. Мудрик, О. Р. Боярчук, Л. А. Волянська, Е. І. Бурбела // Медична освіта. 2020. - № 3. - C. 94-99. DOI https://doi.org/10.11603/ me.2414-5998.2020.3.11447.

3. Герасимчук П. О. Впровадження інноваційних технологій у викладання навчальної дисципліни на кафедрі загальної хірургії / П. О. Герасимчук, А. В. Павлишин, Д. Б. Фіра // Медична освіта. - 2021. - № 1. - С. 17-22. DOI https://doi.org/10.11603/me.2414-5998.2021.1.11776.

4. Інновації у медичній освіті: інтегративний підхід до діагностики, лікування та профілактики захворювань / І. Я. Криницька, М. І. Марущак, І. М. Кліщ, Н. В. Петренко // Медична освіта. - 2018. - № 4. - С. 34-37. DOI https://doi.org/10.11603/me.2414-5998.2017.4.8368.

5. Нагорний В. В. Інтерактивна лекція як сучасна форма викладання дисципліни у вищій школі / В. В. Нагорний, Н. О. Нагорна, Д. М. Сінченко // Актуальні

\section{References}

1. Biliaieva, O.M. (2015). Suchasna akademichna lektsiia [Modern academic lecture]. Svit medytsyny ta biolohii The World of Medicine and Biology, 4(53), 143-146 [in Ukrainian].

2. Mudryk, U.M., Boiarchuk, O.R., Volianska, L.A., \& Burbela, E.I. (2020). Vykorystannia aktyvnykh form navchannia ta suchasnykh informatsiinykh tekhnolohii yak zasobu intensyfikatsii navchalnoho protsesu [Use of active methods of training and modern information technologies as a means of intensifying the educational process]. Medychna osvita - Medical Education, 3, 94-99 [in Ukrainian].

3. Herasymchuk, P.O., Pavlyshyn, A.V., \& Fira, D.B. (2021). Vprovadzhennia innovatsiinykh tekhnolohii u vykladannia navchalnoi dystsypliny na kafedri zahalnoi khirurhii [Introduction of innovative technologies in teaching the academic discipline at the department of general surgery]. Medychna osvita - Medical Education, 1, 17-22 [in Ukrainian].

4. Krynytska, I.Ya., Marushchak, M.I., Klishch, I.M., \& Petrenko, N.V. (2018). Innovatsii u medychnii osviti: intehratyvnyi pidkhid do diahnostyky, likuvannia ta profilaktyky zakhvoriuvan [Innovations in medical education: integrative approach to disease diagnostics, treatment and prevention]. Medychna osvita - Medical Education, 4, 34-37 [in Ukrainian].

5. Nahornyi, V.V., Nahorna, N.O., \& Sinchenko, D.M. (2016). Interaktyvna lektsiia yak suchasna forma vykladannia dystsypliny u vyshchii shkoli [Interactive lecture as a modern form of teaching the subject in higher school]. Aktualni

E-mail address for correspondence: kosenkost@gmail.com питання підготовки майбутніх фармацевтичних та медичних фахівців в умовах сучасної освіти : зб. матеріалів Всеукр. наук.-практ. конф., 15 лют. - 24 берез. 2016 р. - Житомир : КВНЗ «Житомирський базовий фармацевтичний коледж ім. Г. С. Протасевича», 2016. С. 187-189. - Режим доступу : http://dspace.zsmu.edu.ua/ handle/123456789/4077.

6. Огреніч М. А. Інтерактивна лекція як одна з новітніх форм навчання / М. А. Огреніч // Науковий вісник Південноукраїнського національного педагогічного університету ім. К. Д. Ушинського. - 2011. - № 11-12. C. 161-166. - Режим доступу : http://nbuv.gov.ua/UJRN/ punpu_2011_11-12_27.

7. Сучасні методи викладання медичних дисциплін у вищій школі / Л. А. Гай, Ю. В. Сухін, В. Ф. Венгер [та ін.] // Медична освіта. - 2016. - № 1. - С. 15-18. - Режим доступу : http://nbuv.gov.ua/UJRN/Mosv_2016_1_6.

8. Харицька С. В. Сучасна інтерактивна лекція з методики викладання іноземних мов і культур / С. В. Харицька, С. І. Шевченко // Наукові записки Національного університету «Острозька академія». Серія «Філологічна». - 2015. - Вип. 56. - С. 315-317. - Режим доступу : http://nbuv.gov.ua/UJRN/Nznuoaf_2015_56_114.

pytannia pidhotovky maibutnikh farmatsevtychnykh ta medychnykh fakhivtsiv $v$ umovakh suchasnoi osvity: zbirnyk materialiv Vseukrainskoi naukovo-praktychnoi konferentsii - Topical issues of training of future pharmaceutical and medical specialists in the conditions of modern education: collection of writings of the All-Ukrainian Research and Practice Conference. (pp. 187-189). Zhytomyr: KVNZ «Zhytomyrskyi bazovyi farmatsevtychnyi koledzh im. H. S. Protasevycha» [in Ukrainian].

6. Ohrenich, M.A. (2011). Interaktyvna lektsiia yak odna z novitnikh form navchannia [Interactive lecture as one of the latest forms of study]. Naukovyi visnyk Pivdennoukrainskoho natsionalnoho pedahohichnoho universytetu im. K. D. Ushynskoho - Scientific Bulletin of K. D. Ushynskyi South Ukrainian National Pedagogical University, 11-12, 161-166 [in Ukrainian].

7. Hai, L.A., Sukhin, Yu.V., Venher, V.F., Muksen, Saied, \& Serdiuk, V.V. (2016). Suchasni metody vykladannia medychnykh dystsyplin u vyshchii shkoli [Modern methods of medical disciplines teaching in higher school]. Medychna osvita - Medical Education, 1, 15-18 [in Ukrainian].

8. Kharytska, S.V., \& Shevchenko, S.I. (2015). Suchasna interaktyvna lektsiia z metodyky vykladannia inozemnykh mov i kultur [Modern interactive lecture on methods of teaching foreign languages and cultures]. Naukovi zapysky Natsionalnoho universytetu «Ostrozka akademiia». Seriia «Filolohichna»-Academic writings of the National University of Ostroh Academy. Series “Philological”, 56, 315317 [in Ukrainian].

Received 20.09.21 Recommended 29.09.21 